\title{
UJIAN NASIONAL MENGKEBIRI KEDAULATAN GURU
}

\author{
KH. Bustomi Arisandhi, S.H, M.H
}

\begin{abstract}
Abstraksi
Stardisasi telah menjadi pilihan Kebijakan pendidikan di Indonesia, sebagai memenuhi dari pentingnya lokal, nasional dan global. ISO 9000 adalah sebagai standardisasi internasional kualitas pendidikan yang telah dikompromikan oleh banyak negara di dunia telah memberikan pelayanan terbaik dan memberikan harapan konsumen pendidikan. Standarisasi kelulusan siswa di Indonesia adalah Ujian Nasional, oleh karena pelaksanaan ini telah kehilangan nilai kejujuran, kebaikan dan karakter pendidikan kita. Karena alasan pengguna standardisasi Ujian Nasional tidak sebagai salah satu di semua ukuran fundamental sukses nasional pendidikan di Indonesia. Ujian Nasional telah kehilangan kedaulatan guru karena tidak memberikan autoritas sama sekali untuk guru untuk memberikan nilai kepada siswa mereka. Pemerintah perlu mengambil kebijakan lain untuk mengubah Ujian Nasional yang satu dapat menciptakan kreativitas siswa dan guru untuk tidak membunuh demokrasi kita.
\end{abstract}

Kata Kunci: Ujian Nasional, Standardisasi,Kedaulatan Guru

\section{A. Pendahuluan}

Perubahan merupakan suatu keniscayaan. Karena itu setiap bangsa yang ingin tetap eksis dan berkembang dituntut untuk mampu mengantisipasi setiap perubahan dan perkembangan politik, ekonomi, 
pendidikan, sosial dan budaya. Abad ke-21 telah memunculkan persaingan global dan perdagangan bebas yang merasuki seluruh sistem kehidupan bangsa. Bahkan pendidikan mengalami pergeseran nilai dalam tataran pertarungan idealisme versus realisme, dan rasionalisme versus eksistensialisme.

Menurut Syafaruddin (2008), ada tiga alasan utama perlunya perubahan termasuk dalam bidang pendidikan. Pertama, yaitu: struktur organisasi yang kaku atau sangat mendominasi pada perusahaan era industri pada masa lalu digantikan dengan model sistem baru. Hampir setiap model baru, bekerja atas sistem berpikir untuk mengejar tujuan peningkatan berkelanjutan dan kualitas yang konsisten. Metode manajemen modern menggunakan analisis statistik menuju titik perbedaan dalam proses.

Kedua, struktur baru organisasi dibedakan dari keadaan masa kini. Organisasi sekolah saat ini dirancang dalam lingkaran guru dan pengajaran dibanding pendekatan berdasarkan pelajaran dan pembelajaran. Setiap pelajar memiliki sendiri rencana pembelajaran dan tujuan diputuskan secara bersama oleh guru dengan orang tua siswa, serta masukan dari siswa juga. Perbedaan jenis pengaturan pembelajaran diperoleh dari pribadi pelajar yang tergantung atas kebutuhan mereka.

Ketiga, struktur baru organisasi berbeda dari yang ada saat ini, menggunakan kemampuan teknologi baru diperoleh untuk memudahkan peningkatan semakin luas dalam semua prosedur pengajaran, penguasaan informasi, dan metode pembelajaran.

Menurut Buchori (1994), fungsi sistem pendidikan nasional menopang pengembangan ilmu pengetahuan dan teknologi adalah menyiapkan bangsa sehingga memungkinkan usaha pengembangan iptek yang sesuai aspirasi nasional, dan menyiapkan bangsa untuk mampu menyesuaikan diri dengan perubahan yang ditetaskan dari kemajuan iptek. 
Sistem pendidikan dewasa ini yang akarnya dalam era industri, dapat ditingkatkan atau direstrukturisasi supaya sesuai dengan karakteristik baru masyarakat informasi. Begitupun standar hidup masyarakat ditingkatkan secara berkelanjuatan, maka harus dibuat perubahan fundamental lain dalam sistem pendidikan. Semua komponen sekolah dan perguruan tinggi perlu diubah secara sengaja, terarah dan berkelanjutan. Perubahan yang disengaja adalah pekerjaan manajemen melalui perubahan yang direncanakan (planned change). Kebijakan Departemen Pendidikan Nasional, Kebijakan Dinas Pendidikan, serta kebijakan sekolah harus bermuara kepada peningkatan derajat pemerataan mutu, dan pemberdayaan masyarakat menuju bangsa berbudaya, beradab, dan bermartabat.

\section{B. Standarisasi Pendidikan}

Dalam dinamika kehidupan bangsa-bangsa pada abad ke-21, persoalan standar produk dan pelayanan semakin mengemuka sehingga menuntut respon setiap bangsa. Lahirnya standarisasi bermula dari dunia industri sebagai suatu kebutuhan organisasi. Tujuannya adalah memudahkan proses produksi, distribusi, dan layanan penjualan. Institusi industri dan pelayanan umum yang tidak memenuhi standar produk dan layanan yang diinginkan pelanggan akan kalah bersaing dalam interaksi jaringan ekonomi. Karena itu diperlukan kesepakatan bersama mengenai standar mutu yang diinginkan, bahkan ada tuntutan membuat standarisasi dalam menghasilkan barang, pelayanan dan jasa lebih efektif, efisien, cepat, memenuhi selera konsumen dan harapan semua stakeholders. Faktanya telah muncul kesepakatan internasional dalam kerangka standar mutu dengan istilah International Standardization Organization (ISO). Semua bidang industri dan perdagangan, bahkan bidang jasa mulai menerapkan ISO sesuai dengan tuntutan dan wilayah cakupan industri, perdagangan, dan jasa yang dilaksanakan. 
Menurut Arcaro (1999), mutu adalah sebuah proses terstruktur untuk memperbaiki keluaran yang dihasilkan. Sedangkan Everard (2004) menyimpulkan bahwa mutu (quality) dipahami sebagai keunggulan (exellence), dengan alasan cocok dengan tujuan. Selanjutnya berkembang secara umum bahwa mutu adalah mencapai apa yang diharapkan pelanggan. Pelanggan sekolah mencakup orang tua, murid, pegawai, pemerintah yang kemudian memantau harapan dan kepuasan, apakah tercapai atau tidak dalam pelaksanaan pendidikan di sekolah.

Merujuk kepada Hoy, et. Al. (2000), dikatakan bahwa: “Quality is often defined in term of outcomes to match a customer's satisfaction ". Dalam konteks sekolah, kepuasan orang tua, masyarakat dan pihak terkait (stakeholders) terhadap lulusan berkualitas dan pelayanan sekolah yang baik merupakan kata kunci mutu sekolah yang diandalakan. Kesesuaian hasil dengan kepuasan pelanggan adalah indikator mutu yang harus dikejar setiap sekolah.

Setiap bangsa sepatutnya belajar dari negara maju yang telah menerapkan standar pendidikan yang baik dalam mempercepat kemajuan pendidikannya lebih awal dalam momentum mengakhiri dua dasawarsa abad ke-20. Seperti halnya Inggris dengan filosofi British Standard (BS) 5750, dan secara internasional dengan International Standardization Organization (ISO) 9000. Semua aktivitas dituntut untuk menghasilkan pelayanan yang baik sesuai dengan prosedur yang tertata jika sistem kualitas dikonfirmasikan dengan BS 5750 dan ISO 9000 (Sallis, 1993).

Standarisasi adalah proses yang menetapkan standar-standar yang dijadikan patokan untuk menghasilkan sesuatu lebih baik dan berkualitas unggul sesuai dengan harapan konsumen ( Tilaar, 2006: 21). Dengan adanya standar maka harapan masa depan bisa diprediksi, apalagi dengan dukungan kemajuan sains dan teknologi yang semakin imperatif dalam kehidupan bangsa. Dalam konteks pendidikan, bahwa standarisasi hanya merupakan ikhtiar manusia dalam mengantisipasi dan memprediksi hasil pendidikan di masa depan. Persoalan ini berkenaan dengan persoalan 
manajemen pendidikan. Namun hal itu, hanya merupakan bagian kecil dari upaya memberikan pelayanan yang memenuhi harapan pelanggan pendidikan.

Melaksanakan sistem yang ada dalam standarisasi itu bukan hal yang mudah, karena melibatkan modal yang memenuhi persyaratan bagi sumber daya dan ketersediaan staf. Setiap orang dalam lembaga memerlukaqn pemahaman atas implikasi dan bekerja atas sistem dan mengikuti prosedur pelaksanaannya. Banyak guru yang belum mampu memenuhi persyaratan standarisasi yang dimaksud dalam konteks pendidikan.

Mengacu kepada pendapat Tilaar (2006:136) di sini muncul prokontra standarisasi pendidikan. Ada kelompok yang mempercayai standarisasi pendidikan akan meningkatkan proses belajar peserta didik dengan kondisi tertentu. Disadari bahwa standarisasi pendidikan perlu dengan memenuhi syarat-syarat, diantaranya:

(1) standar yang akan dilaksanakan merefleksikan kebijakan (wisdom) dari orang tua dan guru,

(2) penyusunan dan penetapan standar isi atau kurikulum haruslah secara hati-hati,

(3) standar yang telah ditentukan hendaknya dapat dilaksanakan oleh guru yang profesional,

(4) kemajuan akademik di sekolah tidak dapat semata-mata diukur melalui tes akhir atau ujian akhir,

(5) standar haruslah memberikan kesempatan yang sama untuk semua peserta didik.

Begitupun ada kelompok yang menolak standarisasi. Sikap kontra ini adalah dengan memperhatikan perbedaan dalam masyarakat demokrasi. Tampaknya, standarisasi pendidikan lebih banyak dipengaruhi keputusankeputusan bisnis dan politis, serta para ahli pendidikan. Sedangkan orang tua dan masyarakat dengan pendapat berbeda kurang dilibatkan. Naifnya, bahwa standarisasi telah menentukan tujuan yang terletak di luar proses 
pendidikan itu sendiri. Bahkan standarisasi ditentukan oleh pejabat birokrasi pendidikan, yang tidak begitu mengenal dekat apa yang terjadi dan dipraktikkan dalam proses pendidikan di sekolah. Padahal, sekolah mempunyai otoritas tinggi, dalam hal ini, guru untuk melakukan evaluasi terhadap kemajuan belajar peserta didik.

Dengan demikian, sejatinya evaluasi terhadap kemajuan proses pembelajaran peserta didik terletak pada guru dan masyarakat lokal. Justru dengan otoritas pada guru dan masyarakat lokal maka wujud demokrasi pendidikan akan terlaksana. Efektifitas pembelajaran atau efektifitas sekolah ditentukan oleh interaksi komponen sekolah, baik dalam pembelajaran, manajemen, kepemimpinan maupun hubungan eksternal dengan komite sekolah, dan warga masyarakat lokal. Otoritas yang dipaksakan dari atas tentang kebijakan standarisasi justru merusak nilainilai demokrasi yang sudah mulai dihargai sejak reformasi politik dan pemerintahan pada era otonomi daerah.

\section{Standarisasi Kelulusan Siswa}

Dalam konteks pembaruan pendidikan nasional, kebijakan standarisasi lulusan yang penuh polemik mengundang berbagai pendekatan dalam mensikapi kebijakan standarisasi. Sebenarnya standarisasi mutu pendidikan nasional dengan Ujian Nasional (UN) diharapkan memotivasi semua komponen persekolahan dan pendidikan untuk memacu upaya-upaya manajerial yang dapat dipertanggung jawabkan untuk mencapai mutu tinggi. Dengan demikian maka kebijakan standarisasi merupakan kebaikan manajerial dan bahkan mendorong sekolah menerapkan mutu terpadu. Tetapi, siapkah kepala dan personel sekolah mengelola sekolahnya dengan manajemen mutu terpadu untuk mencapai standar mutu pendidikan nasional?

Standarisasi lulusan dengan mengacu kepada hasil UN yang disepakati adalah menjangkau keperluan masa depan. Tetapi harus diingat bahwa standarisasi dengan hasil UN hanya standar kelulusan 
dan bukan mutu pendidikan yang sesungguhnya. Sebab seperti halnya BS 5750 atau ISO 9000 hanya penataan standar bagi sistem mutu. Hal ini tidak menyusun standar lembaga atau apa yang akan dicapai oleh siswa. Justru pimpinan dan staf sekolah bersama dengan pelanggan melihat untuk siapa akuntabilitas standar pembelajaran itu dibuat. Jadi, standarisasi bukan perlakuan nasional terhadap sekolah supaya bermutu, tetapi tergantung kembali kepada masing-masing sekolah untuk mencapai prestasi sesuai dengan standar yang ditetapkan.

ISO 9000 hanya merupakan suatu seri dari International Standard for Quality System. Adapun sistem tersebut membuat rincian mengenai tuntutan dan kombinasi untuk desain serta assesment (penilaian) dari sistem manajeman. ISO 9000 tidak menjamin konsistensi standar antara berbagai lembaga. Hal ini penting sebagai pertimbangan sebab banyak perhatian dari berbagai negara dalam memberikan kebijakan pendidikan berbeda, karena itu setiap negara harus memperhatikan keperluan sesuai kondisinya dalam memenuhi ISO 9000. Jadi bila suatu lembaga memperoleh ISO 9000, baru merupakan satu langkah pertama dalam membina budaya mutu (Syafaruddin, 2008)

Perolehan sertifikasi ISO 9000 sebenarnya merupakan tujuan akhir. Lulusnya seseorang dari ujian akhir belum berarti akhir dari perkembangan seseorang. Kelulusan tersebut hanya menyatakan bahwa telah dicapai minimum standar, tetapi bukan berarti hasil atau produk yang dicapai dapat memenangkan persaingan dengan kompetitor. Untuk itu diperlukan langkah; mempertahankan standar yang telah dicapai, mengadakan upayaupaya perbaikan dalam efektivitas dan efisiensi memenuhi standar tersebut, kemudian melakukan inovasi untuk peningkatan standar yang baru (Tilaar, 2006).

Standarisasi mutu lulusan dengan mengacu kepada UN adalah suatu hal mudah, tetapi yang lebih akuntabel sebenarnya bagaimana menyiapkan perangkat sumber daya dan lingkungan yang kondusif sehingga memungkinkan setiap sekolah mampu mencapai standar yang 
dimaksudkan. Itu berarti, pekerjaan manajemen pendidikan nasional, manajemen pendidikan di daerah dan bahkan manajemen sekolah semakin berat dan menantang. Suatu hal yang penting dilakukan adalah menyeleksi kepala-kepala sekolah yang mampu, terpercaya dan visioner melalui sistem yang baik untuk menangani sekolah-sekolah dalam rangka memenuhi standarisasi pendidikan nasional. Khususnya masalah mengejar standar kelulusan tanpa disertai kebohongan-kebohongan yang bekerja sama dengan peserta didik yang menyebabkan terperosok ke jurang kebodohan yang berkepanjanagan.

Sebagaimana yang ditegaskan oleh Tilaar (2006) bahwa pendidikan yang mematikan demokrasi mulai terlihat dalam pelaksanaan Ujian Nasional yang homogen untuk seluruh Indonesia, penentuan kelulusan peserta didik oleh Badan Standar Nasional Pendidikan (BSNP) tanpa menghormati kebebasan guru di muka kelas dengan berkedok untuk meningkatkan mutu pendidikan nasional, BSNP telah merupakan suatu mesin raksasa pendidikan yang mengatur segala-galanya tanpa memberikan peluang terhadap tumbuhnya kreativitas dan mematikan demokrasi.

Banyak yang mensinyalir bahwa BSNP berlindung di balik peningkatan mutu, tetapi ada maksud tersembunyi yang secara jujur bukan usaha meningkatkan mutu yang dipercepat, tetapi pengukuran hasil yang diutamakan. Standarisasi bertujuan sebagai upaya menata standar pendidikan, karena itu pemerintah daerah dan sekolah harus disiapkan untuk merancang peningkatan mutu. Sekolah perlu diberdayakan secara simultan, progresif, dan antisipatif untuk melewati daya saing di daerah, menuju daya saing nasional dan selanjutnya daya saing global (Syafaruddin, 2008).

Pemerintah selalu menaikkan nilai standarisasi kelulusan siswa setiap tahunnya. Kebijakan pemerintah tersebut dilandasi semangat baru tentang kualitas pendidikan. Berbagai pro dan kontra diutarakan oleh masyarakat seiring meningkatnya nilai standarisasi kelulusan siswa. Sebagian masyarakat menyambut baik kebijakan tersebut karena dianggap akan 
meningkatkan mutu pendidikan, dan sebagian lagi menolak karena dianggap mempersulit siswa dan tujuannya bukan sebagai peningkat mutu pendidikan tetapi malah sebaliknya akan merosotkan mutu pendidikan.

Pada tahun 2004, peningkatan angka dari 3,01 menjadi 4,01 telah menimbulkan kekhawatiran siswa yang tidak lulus akan mencapai 40 persen. Ternyata kekhawatiran ini tidak terbukti karena Depdiknas melakukan konversi nilai UAN dengan cara mengatrol nilai kurang dan pengurangan nilai bagus, sehingga angka ketidaklulusan bisa ditekan serendah mungkin. Dengan menekan angka ketidaklulusan ini, Depdiknas ingin menunjukkan bahwa kecemasan masyarakat tidak terbukti. Yang tidak disadari, tindakan ini justru akan memicu kecemasan masyarakat atas kompetensi dan integritas para pembuat kebijakan di bidang pendidikan (Kompas, 15 Juni 2004). Konversi nilai ini merupakan tindakan bodoh dan mengisyaratkan bahwa UAN yang dilaksanakan dengan dana besar tidak memiliki arti dan hanya dijadikan tradisi tahunan. Lebih tepatnya, UAN tidak diperlukan lagi karena hanya akan menghabiskan dan memubazirkan uang negara bila nilai UAN direkayasa atau tidak sesuai dengan hasil akhir.

Pada tahun 2006 angka kelulusan UN dipatok dengan nilai ratarata 5,0 dengan nilai minimal rata-rata 4,25 atau boleh salah satu nilainya 4,0 dengan catatan nilai lainnya harus 6,00. Sedangkan tahun 2008 nilai minimal rata-rata naik menjadi 5,00 atau boleh salah satu nilainya 4,0 dengan catatan nilai lainnya harus 6,00. Menurut Susilo (2007), kegilaan dalam melakukan manipulasi semakin marak. Ironisnya, pemerintah dalam hal ini Depdiknas seakan menutup mata dan tidak mau tahu dengan kecurangan tersebut. Mereka hanya menegaskan bahwa sekolah harus bisa meluluskan siswanya dengan nilai yang baik, tidak menegaskan untuk jujur dalam UAN supaya nilai standarisasi siswa benar-benar menjadi indikator mutu pendidikan. Alasannya sangat klasik yaitu tidak mau dicap tidak becus dalam menjalankan tugasnya dikarenakan banyak siswa yang tidak lulus. 
A Hidayatullah $\mathrm{Al}$ arifin mengemukakan berbagai modus operandi dari rencana "curang" yang berkembang antara lain: Pertama, sikap permisif, artinya membolehkan antar siswa saling bekerja sama, siswa yang pandai diwajibkan membantu siswa lainnya yang kurang pandai. Kedua, guru atau petugas mengedarkan kunci jawaban bersamaan dengan guru atau petugas tersebut meminta tanda tangan presensi pengawas pada tiap-tiap ruang ujian. Ketiga, menganjurkan kepada siswa untuk tidak mengerjakan atau mengosongkan jawaban pada soal-soal yang memang siswa tidak bisa mengerjakannya. Di kandung maksud jawaban-jawaban kosong tersebut nanti akan diisikan petugas. Keempat, dengan memanfaatkan alat komunikasi HP, yaitu mengirimkan kunci jawaban melalui SMS . Modus lain yang perlu diwaspadai adalah kemungkinan soal bocor sebelum hari pelaksanaan ujian (Kedaulatan Rakyat, 15 Mei 2006).

Tindakan yang dilakukan guru yang membantu siswa dalam mengerjakan soal ujian merupakan bentuk ketidakpecayaan diri guru tersebut. Mereka takut bila banyak siswa yang tidak lulus pada mata pelajaran yang diampu sehingga dimarahi oleh atasan, takut apa yang diajarkan tidak dapat dimengerti oleh siswa, atau bisa juga guru melakukan hal tersebut murni hanya ingin membantu siswa, lebih tepatnya membantu siswa untuk lebih bodoh.

Seharusnya pemerintah tidak terlalu bernafsu menaikkan nilai standarisasi kelulusan siswa. Bila angka kelulusan pada nilai standarisasi tidak mencapai $80 \%$, untuk tahun berikutnya tidak perlu dinaikkan sampai angka kelulusan mencapai $80 \%$. Begitulah seterusnya sampai siswa benarbenar mampu lulus dengan nilai standarisasi yang telah ditetapkan murni tanpa ada kecurangan.

Menurut Susilo (2007), untuk menghindari terjadinya kecurangan dalam UN, Depdiknas harus bertindak tegas dengan cara menghimbau sekolah-sekolah untuk jujur dan tidak malu apabila banyak siswa yang tidak lulus. Bila ada sekolah yang curang maka pemerintah memberikan sanksi yang akan membuat oknum jera. Apabila ada sekolah yang angka 
kelulusannya sangat rendah yaitu di bawah 50\%, pemerintah tidak langsung menyalahkan kepala sekolah tetapi berusaha mencari tahu penyebab kegagalan sekolah tersebut dan membantu mengatasinya dengan melibatkan sekolah-sekolah lain. Mungkin dengan cara itu akan terlihat peningkatan mutu pendidikan walaupun waktunya lama. Tetapi itu lebih baik dari pada meningkatkan mutu pendidikan dengan tergesagesa sehingga menyebabkan penurunan moral karena menghalalkan segala cara untuk mencapai standar.

\section{Ujian Nasional Dan Kedaulatan Guru}

Ujian Nasional menjadi momok tersendiri bagi peserta didik dan guru. Artinya peserta didik yang mendapat peringkat pertama di kelas pun dapat gagal karena UN. Hal ini dikarenakan ketika pada hari Ujiaan Nasional mereka mendapat nilai di bawah standar, Sedangkan guru sendiri tidak memiliki kewenangan sedikit pun mengenai hasil UN. Pendidikan yang telah lama dijalani kandas oleh hasil ujian dalam waktu tidak lebih dari empat hari. Guru telah kehilangan kedaulatannya. Artinya, pergaulan, pendidikan, dan senda gurau yang telah berlangsung tidak pernah dihargai oleh pemerintah. Pemerintah melalui Ujian Nasional telah menjadi hakim yang dapat memutuskan semuanya.

Guru sebagai individu yang telah mengetahui seluk beluk dan kemampuan peserta didik tidak mampu berbuat banyak. Mereka tidak diberi kewenangan sedikitpun untuk menilai apakah peserta didiknya dapat lulus atau tidak. Padahal sesuai dengan pasal 5 ayat (1) dan pasal 61 Ayat (2) Undang-undang Sistim Pendidikan Nasional, seharusnya evaluasi hasil belajar dan penentu kelulusan peserta didik dilakukan oleh pendidik/guru dan satuan pendidikan/sekolah.

Kedaulatan guru sebagai insan pendidik dengan serta merta dicabut oleh UN. Keadaan ini semakin memperparah kondisi pendidikan Indonesia. 
Artinya pendidikan Indonesia masih bertumpu pada nilai-nilai akademis (kognitif) dan mengesampingkan nilai-nilai kecerdasan yang lain.

Pendidikan Indonesia masih sangat mementingkan hasil daripada proses. Artinya, pendidikan yang selama ini dijadikan basis penyadaran dan pendewasaan tidak lebih diukur dari nilainilai yang dapat dibuat. Materi kecerdasan yang lain, seperti kecerdasan emosional dan spiritual tidak tersentuh dan dihargai sama sekali.

Menjelang UN, peserta didik ditekan sedemikian rupa untuk mengikuti jam tambahan. Hal ini dilakukan guna mengejar materi yang belum selesai dan mengenalkan peserta didik soal-soal UN. Banyak waktu yang sedianya digunakan peserta didik refreshing dan bercanda dengan teman direnggut sedemikian rupa oleh UN. Hal tersebut masih ditambah beban jam tambahan yang diberlakukan oleh lembaga bimbingan belajar.

Dengan demikian, sudah jelas bahwa sistem pendidikan Indonesia masih mengikuti trend pasar. Artinya, pendidikan Indonesia masih suka bongkar pasang sesuai keinginan pemerintah pusat. Jakarta sering kali dijadikan miniatur pendidikan Indonesia, sehingga apa yang terjadi di Jakarta dengan serta merta diterapkan di daerah. Jadi, daerah sama sekali tidak memiliki kemandirian. Ia dipaksa untuk mengikuti trend Jakarta yang belum tentu sesuai dengan potensi lokal yang ada. Demikian pula dengan para gurunya (Setiawan, 2008).

Pendidik sering kali disalahkan oleh pemerintah, orang tua, bahkan peserta didik. Mereka dianggap tidak mampu membimbing peserta didik dengan maksimal. Ketidakmampuan ini ditunjukkan oleh hasil UN. Ketika hasil UN jelek, guru dituding sebagai penyebab utama. Namun, hal ini berbeda ketika hasil UN menunjukkan hasil maksimal, lembaga bimbingan belajar sering kali mendapat pujian dari berbagai pihak. Peran serta guru yang selama ini menemani siswa dalam pembelajaran tidak pernah dihargai sedikitpun.

Lembaga bimbingan belajar sering kali mengklaim dirinya sebagai pihak yang berjasa meluluskan peserta didik. Ia menuliskannya di berbagai 
media masa lokal dan nasional dengan menyebutkan siswa yang berhasil dibimbingnya beserta nilainya. Hal itu dapat dilihat dari maraknya lembaga bimbingan belajar yang telah "berhasil" mengantarkan siswanya mendapatkan jatah di perguruan tinggi negeri.

Guru yang selama ini berjuang sekuat tenaga dan berupaya walaupun dengan gaji rendah tidak mendapat ruang sedikitpun untuk bicara. Mereka lebih banyak nrimo dengan keadaan yang semakin tidak berpihak. Karena itu, guna mengakhiri periode pengasingan guru, perlu dilakukan upaya bersama.

Menurut Freire dalam The Politic of Education: Culture, Power, and Liberation, relasi yang harus dibangun antara pendidik dan pemerintah adalah evaluasi, bukan inspeksi. Dalam inspeksi, pendidik hanya hanya menjadi obyek pengamatan pejabat dari pusat. Sedangkan dalam evaluasi, setiap orang adalah subjek yang bekerja sama dengan pejabat-pejabat itu dalam melakukan kritik dan menjaga jarak dengan dengan kerja mereka (Setiawan, 2008).

Kurikulum berbasis kompetensi (KBK) yang berpijak pada asumsi bahwa kondisi sekolah di Indonesia tidak sama seharusnya menjadi kerangka dasar bagi pemerintah dalam menerapkannya.Artinya dengan perbedaan kondisi tersebut, seharusnya KBK diterjemahkan sebagai wewenang penuh bagi sekolah untuk mengembangkan dan meningkatkan kualitas pendidikannya. Namun pemerintah masih terlalu mencampuri wewenang sekolah. Sebagai contoh, Ujian Nasional (UN) yang masih sentralistik dengan standar nilai dan soal ujian ditentukan oleh pemerintah jelas bertentangan dengan yang seharusnya dilakukan oleh guru untuk memantau proses, kemajuan dan perbaikan hasil belajar peserta didik secara berkesinambungan. Bukankah di dalam KBK digunakan sistem penilaian authentic assesment yang bertujuan untuk menilai seluruh unsur kemampuan siswa dari aspek kognitif, afektif, dan psikomotorik. Jika masih ada penilaian secara 
nasional yang hanya bertumpu pada kemampuan kognitif siswa, bagaimana mengetahui keberhasilan KBK?

Dengan demikian, UN seharusnya tidak dilakukan secara nasional. Ujian secara nasional hanya akan menambah luka hati pendidik dan mengerdilkan aspek multikulturalisme. Ujian dalam bentuk apapun sudah saatnya menjadi kewenangan guru dalam penilaiannya. Hal ini disebabkan guru lebih mengetahui kapasitas kemampuan peserta didik dibanding pemerintah (Setiawan, 2008).

\section{E. Ketidakadilan Dalam Ujian Nasional}

Ujian Nasional (UN) menurut Peraturan Menteri Pendidikan Nasional RI Nomor 20 Tahun 2005 Pasal 4, dijadikan pertimbangan untuk : (1) penentuan kelulusan peserta didik dari suatu satuan pendidikan, (2) seleksi masuk jenjang pendidikan berikutnya, (3) pemetaan mutu satuan dan/atau program pendidikan, (d) akreditasi satuan pendidikan, dan (5) pembinaan dan pemberian bantuan pada satuan pendidikan dalam upaya peningkatan mutu pendidikan.

Sebuah hal yang edial dalam dunia pendidikan. Pertanyaan yang muncul kemudian adalah apakah UN yang dilakukan tidak lebih dari empat hari, dengan empat mata pelajaran untuk SLTP yaitu Matematika, Bahasa Indonesia, IPA, dan Bahasa Inggris dapat dijadikan standar mutu pendidikan di Indonesia?

Ujian Nasional ternyata menyisakan sejumlah permasalahan. Seorang guru di sebuah SMK di Cilegon harus berbuat hal yang sebaiknya tidak dilakukan, yaitu memukul peserta didik hingga babak belur. Hal ini dilakukan karena rasa jengkel sang guru terhadap peserta didiknya. Sang guru sudah membantu peserta didik menyelesaikan soal ujian agar dapat lulus dengan nilai baik tetapi sang murid tidak dapat menunjukkan niatan yang baik, dia tidak tahu terimakasih. Cara yang dilakukan sang guru tersebut tidak bisa dibetulkan karena dia mengirimkan sejumlah jawaban 
soal via SMS atau potongan kertas kecil yang dibagikan kepada pserta didik (Setiawan, 2008).

Mengapa pahlawan tanpa tanda jasa tersebut melakukan hal demikian? Penyebabnya adalah rasa ketakutan sang guru apabila banyak peserta didiknya yang tidak lulus ujian. Seorang guru dituntut sedemikian rupa agar seluruh peserta didiknya lulus 100 persen. Ketika banyak peserta didik yang tidak lulus, ia pun akan merasa malu. Pada akhirnya reputasi sekolah menurun dan tahun depan sekolah tidak akan mendapatkan peserta didik baru. Intinya, kelulusan 100 persen menjadi patokan baku bagi setiap sekolah.

Bahkan isu pemutasian guru dan kepala sekolah mengiringi peristiwa ini.

Sistem pendidikan Indonesia ternyata masih mengunggulkan kecerdasan intelektual (IQ). Tidak ada sedikitpun ruang untuk kecerdasankecerdasan lain untuk menjadi penentu kelulusan seseorang. Karena itu, tidak aneh jika sekarang banyak peserta didik yang mengalami depresi berat. Hal ini dikarenakan mereka dianggap bodoh dan tidak mampu lagi melanjutkan sekolah ke jenjang berikutnya.

Pemerintah dengan sengaja membiarkan generasi muda produktif bangsa Indonesia menjadi layu sebelum berkembang. Cita-cita besar membangun bangsa Indonesia kandas dikarenakan sistem UN yang tidak memihak.

Ujian Nasional (UN) juga telah mencabut kedaulatan guru. Artinya, guru sebagai orang yang mendidik selama sekian tahun tidak diberi kekuasaan untuk menilai peserta didiknya. Kekuasaan dan kewenangan untuk menyatakan peserta didik lulus atau tidak lulus hanya berada di tangan pemerintah. Seorang guru yang telah bergelut lama dengan peserta didik hanya dapat menahan kesedihan melihat banyak peserta didiknya yang tidak lulus Ujian Nasional.

Guru tidak lebih seperti pekerja kasar. Mereka dipekerjakan tanpa memperdulikan hak-haknya. Jerih payah yang dilakukan selama ini hanya ditentukan dalam waktu empat hari. Ketika banyak peserta didik yang tidak 
lulus, mereka akan divonis tidak mampu mengantarkan peserta didiknya menjadi insan cerdas.

Peter B Sihombing (Kompas, 15 Juni 2004) mengemukakan beberapa dampak yang diakibatkan oleh adanya konversi nilai, yaitu:

1. Depdiknas berada di barisan paling depan dalam pemerkosaan arti nilai ujian. Nilai ujian ujian bukan lagi merupakan cermin kemampuan atau kompetensi siswa, tetapi hanyalah sebagai alat permainan untuk menentukan kelulusan siswa.

2. Depdiknas secara sistematis mengkhianati tujuan dan fungsi ujian nasional yang mereka terapkan sendiri. Dengan dalih meningkatkan motivasi siswa belajar dan meningkatkan mutu lulusan, mereka menetapakan minimal nilai lulus 4,01, di sisi lain mereka grogi melihat kenyataan begitu banyaknya siswa tidak lulus.

3. Hak siswa unggul dirampas. Terjadi pemberhangusan intelektual anak bangsa. Siswa pintar seharusnya diberi penghargaan (Reward) dan bukan malah menghukum mereka dengan sadis dengan menyunat nilai secara besar-besaran. Sehingga terjadi intellectual assassination dan sekaligus character assassination, anak terbaik bangsa dibuat kecewa dan frustasi.

4. Siswa kurang mampu dianugerahi penghargaan besar-besaran demi mencapai target.

5. Peluang lulusan SMA/MA untuk mengikuti berbagai tes/seleksi di berbagai instansi kedinasan menjadi sirna. Hampir semua instansi mengharuskan minimal nilai rata-rata tertentu, misalnya STAN, STT Telkom, Akademi Militer.

6. Depdiknas dengan sengaja merusak citra sekolah-sekolah faforit/unggul. Selama ini masyarakat menggunakan rata-rata NUN sebagai salah satu ukuran keberhasilan sekolah. Dengan adanya konversi nilai dari Depdiknas telah mengakibatkan anjloknya nilai ratarata sekolah unggulan tersebut. 
7. Guru dikecewakan oleh Depdiknas. Siswa dan orang tua siswa hanya tahu bahwa nilai tidak baik. Berarti gurunya tidak becus mengajar. Apakah dengan cara seperti ini Depdiknas menghargai jasa guru-guru di negeri ini?

Ketidakadilan UN semakin menambah deretan persoalan pendidikan di Indonesia. Kebijakan pendidikan selalu berubah ketika para pemimpinnya ganti. Belum lagi sekolah-sekolah yang rusak dan roboh, kesejahteraan guru yang memprihatinkan, dan seterusnya.

Sudah selayaknya UN dijadikan evaluasi sekolah. Artinya kewenangan untuk meluluskan atau tidak meluluskan peserta didik diserahkan sepenuhnya kepada guru sekolah yang ada. Karena memang gurulah yang paling mengetahui tingkat kecerdasan seorang peserta didik. Mereka tidak hanya mengukur tingkat kecerdasan IQ belaka, melainkan kecerdasan-kecerdasan yang lain.

Pemerintah sudah saatnya memikirkan hal lain yang lebih bermakna, yaitu bagaimana meningkatkan kesejahteraan guru dan mitu guru, memperbaiki sekolah yang rusak, dan menjadikan pendidikan Indonesia lebih bermakna dari sekedar mengukurnya dengan nilai-nilai dalam bentuk angka, karena nilai-nilai itu belum tentu mencerminkan kemampuan siswa yang sebenarnya.

\section{F. Menggugat Ujian Nasional}

Setiap tahun, wacana tentang perlu tidaknya Ujian Nasional (UN) dilaksanakan selalu menarik untuk diperbincangkan. Apalagi sejak tahun 2008 pemerintah menetapkan menambah mata pelajaran yang diUN-kan. Di tingkat SLTA untik jurusan Ilmu Pengetahua Sosial (IPS) selain Bahasa Indonesia, Bahasa Inggris, Matematika, masih ditambah lagi tiga mata pelajaran yaitu: Ekonomi, Sosiologi, dan Geografi. Sedangkan untuk jurusan Ilmu Pengetahuan Alam (IPA) ditambah Kimia, Fisika dan Biologi. 
Sebagian pemerhati dan pengamat pendidikan berpendapat bahwa sistem UN tidak memanusiakan manusia, tidak sesuai dengan khittah pendidikan dan mematikan daya nalar peserta didik.

Peserta didik dipaksa mengikuti aturan pemerintah yang jauh dari realitas pendidikan (Setiawan, 2008).

Pendidikan yang merupakan sebuah proses yang mulia, yang berusaha memanusiakan manusia (Freire), pengangkatan manusia muda ke taraf Insani (Driyarkara), dan pemerdekaan (Romo Mangun), tidak menjadi dasar pijakan pemerintah. Pemerintah lebih mementingkan hasil dari pada proses. Pemerintah merasa bangga mampu meluluskan peserta didk dengan nilai rata-rata 5,25 daripada melihat peserta didik mandiri dan mampu berkarya sesuai dengan potensi yang dimiliki. Dengan nilai rata-rata tersebut, konon pendidikan di Indonesia dapat bersaing dengan negaranegara lain.

Pemerintah ternyata masih saja mengikuti pola pikir kaum feodal. Yaitu, lebih bangga dengan gelar yang terpampang didepan dan dibelakang nama. Lebih bangga dengan nilai 10 atau 100 dan mengesampingkan nilainilai yang lain.

Kaum fiodal biasanya anti kritik, mereka menganggap dirinya orang yang paling benar dan pantang untuk dikritik. Hal ini juga ada dalam pola pikir dan laku pemerintah Indonesia. Ia merasa benar dengan apa yang telah diputuskan. Masukkan dan kritikkan hanya dijadikan hiasan dan angin lalu.

Karena itu, tidak heran jika banyak tuntutan dari orang tua, beserta didik, dan praktisi pendidikan mengenai UN tidak pernah ditanggapi serius, kritik dan saran yang disampaikan komponen pendidikan tidak pernah menjadi agenda kerja.

Bahkan, untuk menutupi kekurangan atau membendung unjuk rasa yang menolak diselenggarakannya UN, pemerintah sengaja mengadakan seminar yang dikuti oleh kelompok yang pro UN. Dengan demikian, pemerintah dapat beralasan bahwa tidak benar jika masyarakat dan 
komponen pendidikan di Indonesia menolak UN. Masih ada sebagian kelompok yang mendukung dan setuju dengan UN.

Lebih dari itu, proyek penyeragaman soal UN yang tentunya menggunakan dana APBN selalu saja tidak transparan. Semua serba tertutup. Ketika ada pihak-pihak yang mencoba jujur dan menguaknya, ia akan dimutasi atau bahkan dipecat.

Karena itu, tidak aneh jika banyak guru dan pihak sekolah juga melakukan hal yang tidak transparan. Bahkan mereka rela menggadaikan idealisme agar peserta didiknya lulus semua. Salah satunya dengan memberikan jawaban soal seperempat jam sebelum ujian dimulai. Sebagaimana terjadi di sebuah Sekolah Menengah Atas (SMA) di Jawa Tengah (Setiawan, 2008).

Guru dan pihak sekolah merasa malu dan terancam eksistensinya ketika banyak peserta didik yang gagal UN. Mereka akan mendapat kritik bahkan cemoohan dari orang tua, kepala dinas, bahkan oleh pemerintah kabupaten/kota. Tidak jarang dari mereka yang dimutasi akibat tidak berhasil meluluskan peserta didiknya. Kepala sekolah pensiun dini atau dibebastugaskan karena tidak mampu membawa nama baik sekolah dan pendidikan di sebuah daerah.

Guru dan pihak sekolah pun sangat khawatir jika banyak peserta didiknya tidak lulus. Mereka akan kehilangan pekerjaan karena sepinya peminat atau calon peserta didik yang mendaftar. Hal ini dikarenakan menurunnya citra sekolah akibat banyaknya peserta didik yang tidak lulus. Tentu saja ini sering kali menjadi momok yang menakutkan bagi sekolahsekolah swasta.

Pendek kata, UN telah banyak merampas hajat hidup orang banyak. Karena tidak lulus UN, seseorang bisa minder dan ada yang bunuh diri, sebagaimana yang terjadi di bali dan Sragen Jawa Tengah pada tahun 2007. Karena UN, guru dan pihak sekolah menjadi "pecundang" dengan memberikan jawaban soal kepada peserta didiknya. Karena UN pula, lepala sekolah dimutasi dan pensiun dini. Dan masih banyak lagi hal negatif 
lainnya. Karena itu, setelah melihat realitas yang demikian, pemerintah perlu memikirkan formula yang tepat sebagai pengganti UN. Apabila tidak ada formula yang tepat untuk mengganti kebijakan UN, langkah paling mudah adalah ditiadakannya UN. Biarkan proses belajar mengajar di sekolah "dinilai" oleh guru yang selalu mendampingi dan mendidiknya.

\section{G. KESIMPULAN}

Perubahan bukan semata-mata karena kemajuan sains dan teknologi. Proses pendidikan memegang peranan yang sangat penting, bahkan menjadi faktor signifikan dalam melahirkan pemikiran baru, kreativitas, dan dinamika dalam kehidupan bersama. Perubahan tidak terjadi dari teknologi dan ilmu pengetahuan saja tetapi lahir dari manusia yang kreatif dan inovatif. Sebab perubahan bermula dari perubahan ide, perubahan dalam cara pandang (view of point), atau pandangan dunia.

Sebagai upaya membangun dunia yang diinginkan, diperlukan untuk mencatat setiap aktivitas berkenaan dengan proses program, mencakup proses memilih, intervensi masukan, penilaian disiplin, catatan prestasi, nasihat, dan bimbingan. Hal itulah yang ditempatkan dalam BS 5750 dan ISO 9000, sebagai totalitas disiplin dan aturan sebagai maksud dari penggunaan standarisasi.

Standarisasi pendidikan nasional merupakan tuntutan globalisasi. Bangsa Indonesia hidup di perkampungan global (global village). Terjadi persaingan yang begitu ketat untuk bekerja sama, maka warga negara Indonesia perlu meningkatkan dirinya dalam persaingan global. Agar bangsa Indonesia dapat mandiri dan mampu bekerja sama antar bangsa maka standar SDM lulusan pendidikan juga harus unggul.

Ujian Nasional (UN) sebagai standarisasi mutu pendidikan nasional ternyata belum bisa mencerminkan kemampuan siswa yang sebenarnya, karena dalam implementasinya banyak sekali kecurangan dan 
ketidakjujuran yang dilakukan oleh siswa, guru dan bahkan kepala sekolah. Hal itu menunjukkan adanya ketidakpercayaan diri guru dan pengelola sekolah terhadap apa yang telah dilakukannya selama ini sebagai agen pembelajaran.

Ujian Nasioanal (UN) juga telah mencabut kedaulatan guru dan merampas hajat hidup orang banyak. Guru sebagai pendamping siswa dalam pembelajaran selama bertahu-tahun tidak mempunyai kewenangan sedikitpun untuk menilai hasil belajar siswa, sehingga lulus atau tidak lulusnya siswa hanya ditentukan oleh pemerintah melalui BSNP. Oleh karena itu kebijakan Ujian Nasional ini perlu dikaji ulang oleh pemerintah dengan memperhatikan saran dan masukan dari berbagai pihak yang perduli terhadap peningkatan mutu pendidikan.

\section{DAFTAR PUSTAKA}

Arcaro, Jerome.S. 2005. Pendidikan Berbasis Mutu. Yogyakarta: Pustaka Pelajar.

A Hidayatullah Al Arifin. 2006. Mendambakan Ujian Nasional yang Bersih dan Jujur. Kedaulatan Rakyat: 15 Mei 2006

Hoy, Charles, Colin Bayne Jardin and Margaret Wood. 2000.

Improving Quality in Education. London: Philadelpia.

Peraturan Menteri Pendidikan Nasional RI Nomor 20 Tahun 2005.

Peter B Sihombing. 2004. Batalkan Konversi Nilai UAN. Kompas 15 Juni 2004.

Sallis, Edward. 1993. Total Quality in Education. London: Philadelpia. 
Setiawan, Benni. 2008. Agenda Pendidikan Nasional. Yogyakarta: ArRuzz Media.

Susilo, M.J. 2007. Pembodohan Siswa Tersistematis. Yogyakarta: Pinus.

Syafaruddin. 2008. Efektivitas Kebijakan Pendidikan: Konsep, Strategi, dan Aplikasi Kebijakan Menuju Organisasi Sekolah Efektif. Jakarta: Rineka Cipta.

Tilaar, H.A.R. 2006. Standarisasi Pendidikan Nasional. Jakarta: Rineka Cipta.

Undang-Undang Nomor 20 Tahun 2003 tentang Sistem Pendidikan Nasional. 2003. Jakarta 
